Available online at GSC Online Press Directory

GSC Biological and Pharmaceutical Sciences

e-ISSN: 2581-3250, CODEN (USA): GBPSC2

Journal homepage: https://www.gsconlinepress.com/journals/gscbps

(RESEARCH ARTICLE)

\title{
Assessing Emeria spp and other parasites in the digestive track of guinea fowls (Numida meleagris) farmed in northern Côte d'Ivoire
}

\author{
Soro Ouation Souleymane, Karamoko Yahaya *, Traoré Seïdinan Ibrahima and Yapi Jean Noel \\ Training and Research Unit in the Sciences of Nature, Laboratoire Régional de Korhogo LANADA, Laboratory of Biology \\ and Animal Cytology University Nangui Abrogoua, 02 BP 801 Abidjan 02, Ivory Coast.
}

Publication history: Received on 25 January 2019; revised on 14 February 2019; accepted on 20 February 2019

Article DOI: https://doi.org/10.30574/gscbps.2019.6.2.0015

\begin{abstract}
This study was conducted in four departments of the North of Côte d'Ivoire from November 2016 to October 2017 . The aim of the survey was to identify the gastrointestinal parasites responsible for the numerous mortalities and economic losses observed among guinea fowl breeders in the north of Ivory Coast. Thus, a coprological study of 448 feces emitted from animals or taken directly from the small intestine and caeca of dead animals was conducted in (LANADA). The results reveal the presence of five parasites Eimeria spp; Ascaris spp; strongle spp; Trichurus spp and Taenia spp. Coccidia is most represented with an overall prevalence of 42.85\%, followed by Ascaris spp (16.07\%), strongle spp (14.06\%), Trichuris spp (5.35\%) and Taenia spp (1.33\%). The department of Korhogo has the most rate of coccidia with a prevalence of $77.68 \%$. However, the department of Sinématiali hosts the highest diversity of parasite overall with the presence of the five parasites. Subjects infected are more pronounced during the wet season with the highest prevalence rates in animals over 21 days of age. To increase productivity in Guinea fowl breeding in the north of the country, it would be interesting to offer to breeders, a prophylaxis program adapted to this method of breeding.
\end{abstract}

Keywords: Gastrointestinal; Parasite; Prevalence; Guinea fowl; Numida meleagis; Côte d'Ivoire

\section{Introduction}

The improvement of poultry production, particularly those of a family type, remains a major challenge to meet the ever increasing nutritional needs of people in developing countries. Guinea fowl breeding, which is an integral part of this family poultry farming, faces many constraints, among which young guinea-fowl mortality comes first [1-3]. Indeed, mortality rates ranging from $50 \%$ to $100 \%$ have been recorded in several countries such as Benin, Burkina Faso, and Nigeria etc.

Family poultry farming, in particular that of guinea fowl, occupies an important place in the contribution of animal protein in many African countries, including those in the West African regions [4-6]. In Côte d'Ivoire, fowl breeding is located in the north of the country where it plays an important role in the food and economic income of the populations. However, like many other countries (Benin, Ghana, Burkina Faso, Nigeria), it faces many challenges that slow its development. Among these difficulties, the major constraint remains the mortality of young guinea-fowl. [7] showed that, fowl mortality was influenced by several parameters, the most imminent is parasitic. Although it plays a significant role in the country's supply of animal protein, the guinea fowl has remained almost on the margins of research by the Ivorian scientific community. However, in view of the growing need for animal protein due to the demographic explosion, the Ivorian must consider all the breeding which can product animal protein. Thus, this study which attempts to understand the causes of fowl mortality through a parasitological study in the species. Indeed, several studies have shown that guinea fowl are resistant to major avian diseases of bacterial and viral origin [8], however, according to [9],

\footnotetext{
${ }^{*}$ Corresponding author

E-mail address: y.karamoko@gmail.com
} 
they appear to be susceptible to parasitic diseases. Thus, the aim of this study is to identify and determine the prevalence of gastrointestinal parasites in fowl breeding in northern Côte d'Ivoire.

\section{Material and methods}

\subsection{Study area}

This study was conducted from November 2016 to October 2017 in the north of Côte d'Ivoire, specifically in the communities of Korhogo, Niakaramandougou, Dikodougou and Sinématiali. The northern part of the Côte d'Ivoire is characterized by a Sudanese tropical climate with two major seasons: a rainy season from May to October and a dry season from November to April. The geographical coordinates of the study localities are as follows:

- Korhogo: $9^{\circ} 53^{\prime} \mathrm{N}, 6^{\circ} 49^{\prime} \mathrm{W}$

- Niakaramadougou: $8^{\circ} 40^{\prime} \mathrm{N}, 5^{\circ} 59^{\prime} \mathrm{W}$

- Dikodougou: $9^{\circ} 04^{\prime} \mathrm{N}, 5^{\circ} 46^{\prime} \mathrm{W}$

- Sinematiali: $9^{\circ} 35^{\prime} \mathrm{N}, 5^{\circ} 23^{\prime} \mathrm{W}$

The choice of these communities lies in the fact that they record the largest numbers of breeders.

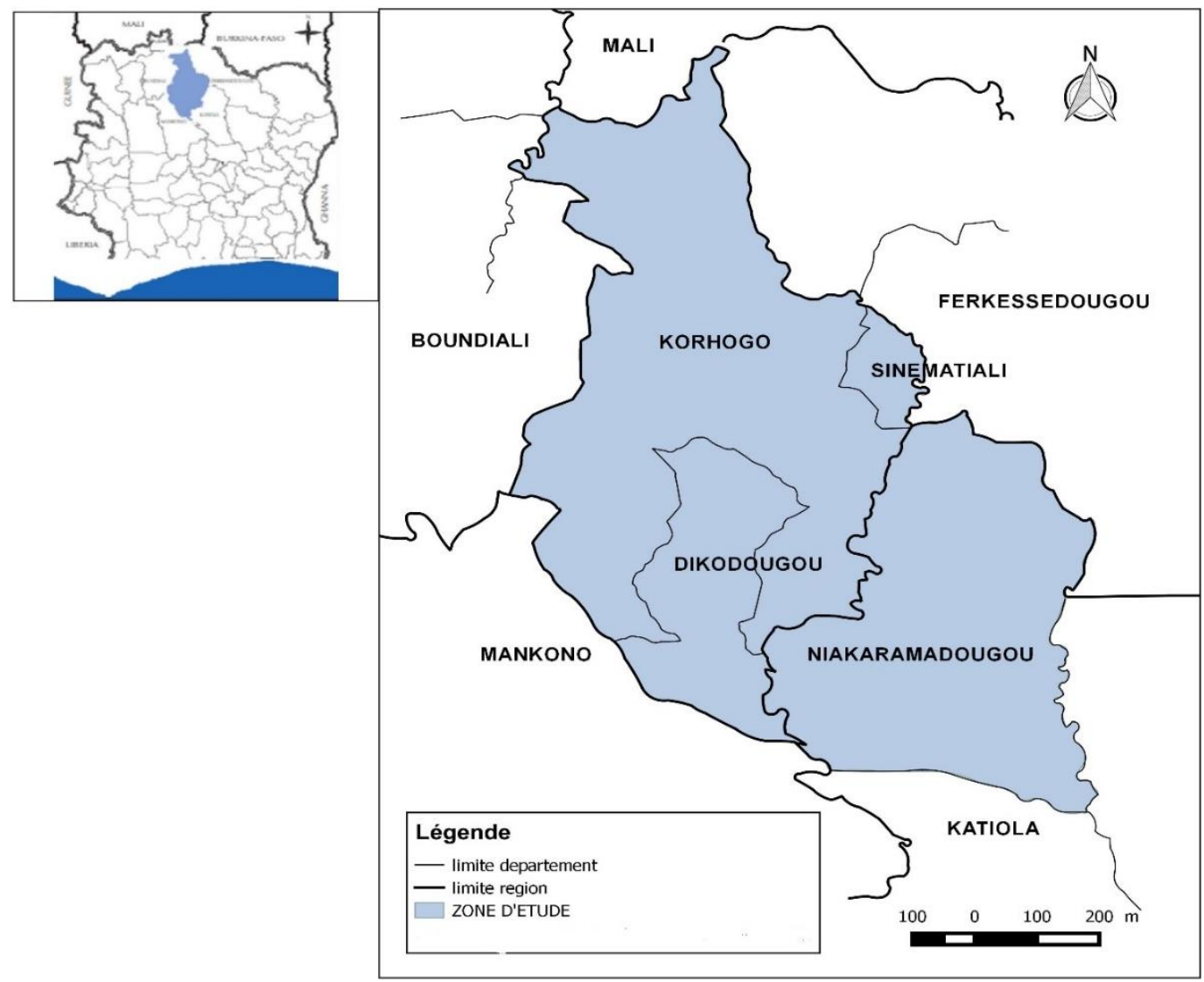

Figure 1 Geographical situation of the surveyed localities

\subsection{Sampling and samples conservation}

Monthly sampling of fresh droppings and dead fowl was conducted on breeding at each locality. For example, the droppings and intestinal and caecal contents of the fowl (taken after dissection) were conditioned in hermetically closed jars and sent to the parasitology laboratory of LANADA (National Laboratory of Support to Agricultural Development). At this level, all the 448 samples were stored in the refrigerator at $4{ }^{\circ} \mathrm{C}$ before being subjected to coprological examination. 


\subsection{Droppings analysis}

The analysis of droppings concerned the qualitative analysis. Thus, droppings were subjected to the flotation technique to determine the possible presence of parasites in their breasts. For each sample, $3 \mathrm{~g}$ of feces were homogenized in 42 $\mathrm{ml}$ of $\mathrm{NaCl}$ solution (density 1.2). After sieving, the mixture was poured into a test tube until a convergent meniscus was obtained. Then a slide was applied to the top of the tube, thus facilitating contact between the slide and the liquid. The slide is removed 10 minutes later and placed and observed to microscope.

\subsection{Statistical analysis}

The proportions of the different parasites obtained in the different study localities were tested to G-test using R version 3.5.1.

\section{Results}

\subsection{Parasitic checkup}

The coprological analysis of all droppings reveals the presence of five (5) species of internal parasites that are Eimeria spp; Strongle spp; Ascaris spp; Taenia spp and Trichuris spp (Figure 2).
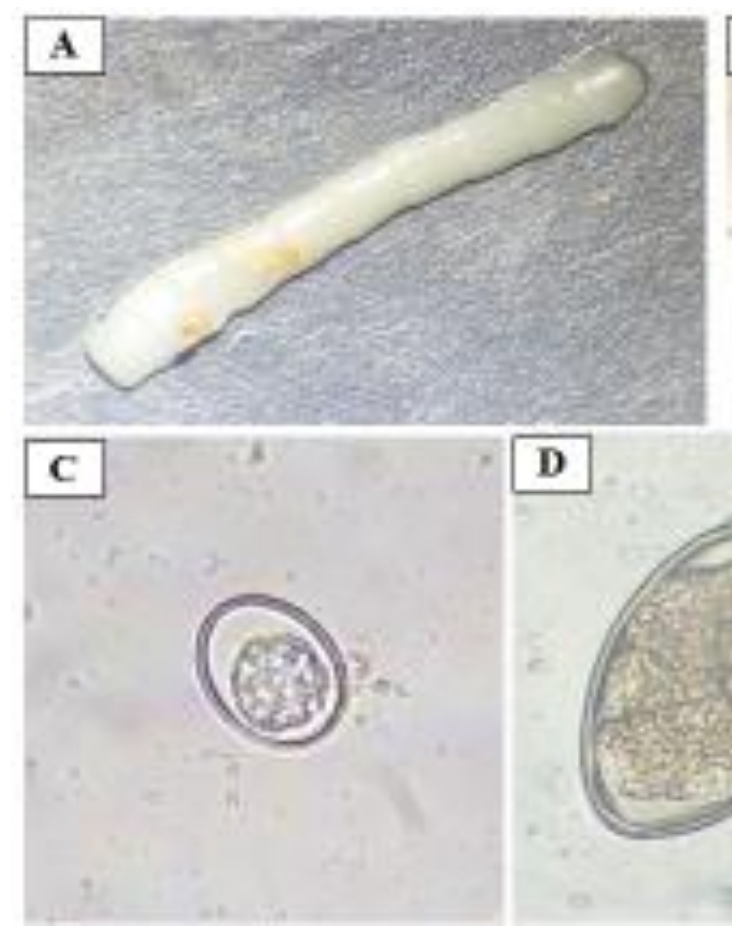
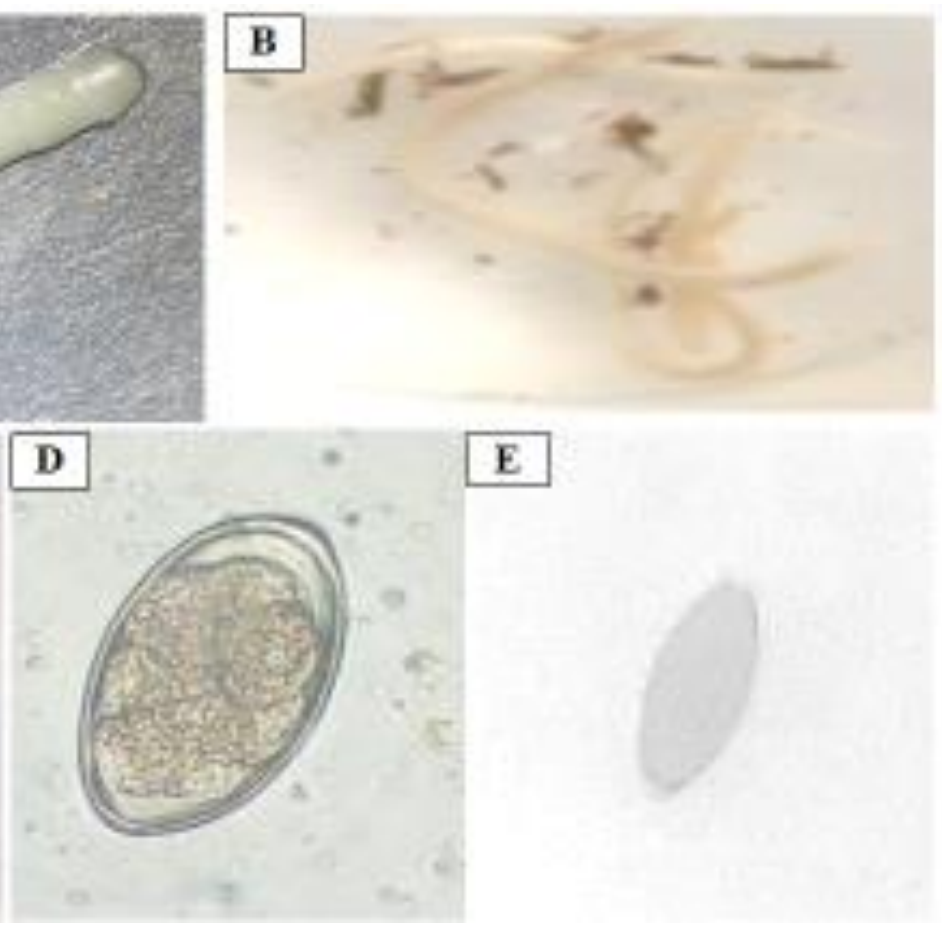

Figure 2 Species of internal parasites encountered in guinea fowl gut. A: Taenia spp; B: Ascaris spp; C: Eimeria oocyst spp; D: Strongle spp egg; E: Trichuris spp egg

\subsection{Parasites distribution}

Coprological analysis of 448 samples collected during the 12 months of the study showed a dominance of Eimeria spp compared to other parasites (Table 1) with a prevalence of $42.86 \%$. This prevalence is 2.67 times higher than that of Ascaris spp (16.07\%) and 3.05 times higher than that of strongle spp (14.06\%). For Trichuris spp (5.35\%) and Taenia spp (1.33\%), their prevalence is 8 times and 32 times lower than Eimeria spp, respectively.

The Ascaris spp and strongle spp, were more abundant in the Department of Sinematiali with prevalences of $40.18 \%$ and $34.82 \%$ respectively. Conversely, none of these parasites were observed in the department of Niakara. The cases of Taenia spp were recorded only in the department of Sinématiali with only 6 cases. The present study shows that the department of Sinématiali is the only locality recording the presence of all parasites. 


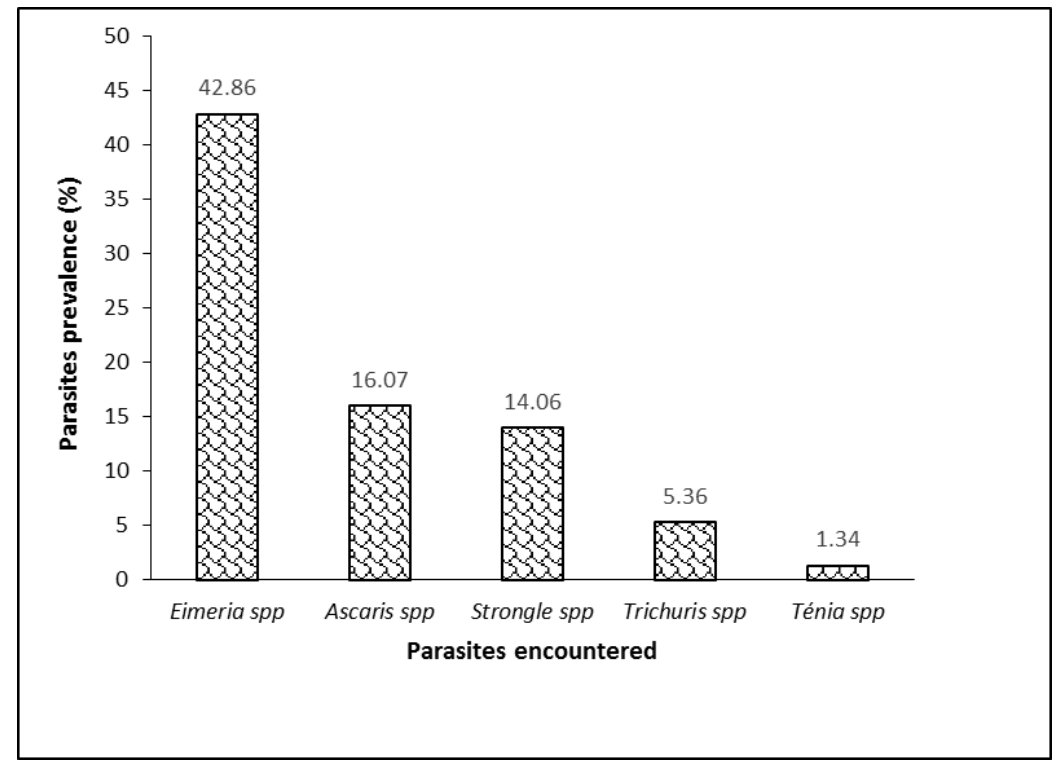

Figure 3 Prevalence of parasites encountered in study area

\subsection{Parasites prevalence by department}

The Table 1 shows the distribution of parasites by department. Of all the parasites encountered, Eimeria sp was present in all study localities. However, Korhogo department has the highest infestation rate to Eimeria spp with a prevalence of $77.68 \%$. This value increases to $13.39 \%$ in Niakaramandougou (Niakara) which is about 6 times lower than in Korhogo. The departments of Sinématiali and Dikodougou (Diko) recorded a prevalence of $58.93 \%$ and $21.43 \%$ of Eimeria spp, respectively.

Table 1 Distribution of the parasites by department

\begin{tabular}{|c|c|c|c|c|c|c|}
\hline \multirow{2}{*}{ Parasites } & \multicolumn{4}{|c|}{ Prévalence (\%) } & \multirow{2}{*}{ G-test } & \multirow{2}{*}{ p-value } \\
\hline & Korhogo & Sinématiali & Diko & Niakara & & \\
\hline Eimeria spp & $77.68^{\mathrm{a}}$ & $58.93^{a}$ & $21.43^{b}$ & $13.39^{\mathrm{b}}$ & 69.06 & $<0.05$ \\
\hline Ascaris spp & $13.39^{a}$ & $40.18^{b}$ & $10.71^{\mathrm{a}}$ & - & 24.37 & $<0.05$ \\
\hline Strongle spp & $10.71^{\mathrm{a}}$ & $34.82^{b}$ & $10.71^{\mathrm{a}}$ & - & 20.26 & $<0.05$ \\
\hline Trichuris spp & - & $8.03^{a}$ & $10.71^{\mathrm{a}}$ & $2.68^{\mathrm{ab}}$ & 5.75 & $<0.05$ \\
\hline Taenias spp & - & 5.36 & - & - & - & $<0.05$ \\
\hline
\end{tabular}

\subsection{Parasites distribution in the different localities according to age group}

The table 2 shows the parasite prevalence of the different localities according to the age of the subjects. In view of the table, parasites such as Eimeria spp; Ascaris spp and strongle spp are present in subjects of all ages, in the localities of Korhogo, Sinématiali and Dikodougou. However, the most infested age groups are 22 to 60 days and older than 60 days, although this last age group is generally less infested than the first. In Korhogo, only the prevalence of Eimeria spp is statistically different from one age group to another. In this locality, the proportion of keets aged to 22 and 60 days, infested by Eimeria spp, is 1.57 and 3.14 times higher respectively than that of age greater than 60 days and 0 to 21 days of age. At the Sinematiali level, the prevalence of different parasites is statistically different from one age group to another. However, in Diko and Niakara the prevalence of different registered parasites remains statistically similar even if the prevalence of the 22 to 60 days age group remains apparently higher. 
Table 2 Distribution of parasites by age group within each locality

\begin{tabular}{|c|c|c|c|c|c|}
\hline \multirow[b]{2}{*}{ Parasites } & \multicolumn{3}{|c|}{ Prevalence (\%) } & \multirow[b]{2}{*}{ G-test } & \multirow[b]{2}{*}{ P-value } \\
\hline & 0 -21 Days & 22 - 60 Days & $\begin{array}{l}60 \text { Days and } \\
\text { more }\end{array}$ & & \\
\hline \multicolumn{6}{|l|}{ Korhogo } \\
\hline Eimeria spp & $12.5^{\mathrm{a}}$ & $39.28^{b}$ & $25.89^{b}$ & 15.99 & $* *$ \\
\hline Ascaris spp & 1.78 & 7.14 & 4.46 & 3.72 & 0.15 \\
\hline Strongle spp & 1.78 & 5.35 & 3.57 & 2.08 & 0.35 \\
\hline Trichuris spp & - & - & - & - & - \\
\hline Taenia spp & - & - & - & - & - \\
\hline \multicolumn{6}{|l|}{ Sinématiali } \\
\hline Eimeria spp & $9.82^{\mathrm{a}}$ & $29.46^{b}$ & $19.64^{\mathrm{ab}}$ & 11.46 & $*$ \\
\hline Ascaris spp & $7.14^{\mathrm{a}}$ & $13.39^{a}$ & $33.92^{\mathrm{b}}$ & 22.04 & $* * *$ \\
\hline Strongle spp & $4.46^{\mathrm{a}}$ & $8.03^{a}$ & $22.32^{\mathrm{b}}$ & 15.46 & $* *$ \\
\hline Trichuris spp & - & $0.89^{a}$ & $7.14^{\mathrm{b}}$ & 5.53 & $*$ \\
\hline Taenia spp & - & & 5.35 & - & \\
\hline \multicolumn{6}{|l|}{ Dikodougou } \\
\hline Eimeria spp & 3.57 & 10.71 & 7.14 & 4.16 & 0.12 \\
\hline Ascaris spp & 1.78 & 5.35 & 3.57 & 2.08 & 0.35 \\
\hline Strongle spp & 1.78 & 4.46 & 4.46 & 1.72 & 0.42 \\
\hline Trichuris spp & - & 5.35 & 5.35 & - & 1 \\
\hline Taenia spp & - & - & - & - & - \\
\hline \multicolumn{6}{|c|}{ Niakaramandougou } \\
\hline Eimeria spp & 1.78 & 7.14 & 4.46 & 3.71 & 0.15 \\
\hline Ascaris spp & - & - & - & - & - \\
\hline Strongle spp & - & - & - & - & - \\
\hline Trichuris spp & - & 1.78 & 0.89 & 0.3 & 0.5 \\
\hline Taenia spp & - & - & - & - & - \\
\hline
\end{tabular}

\subsection{Seasonal distribution}

According to Figure 2, the Eimeria spp and Ascaris spp parasites are less present in the dry season (December-April) compared to the wet season (May-November). In the wet season, these parasites have a double prevalence of the dry season. However, other parasites such as strongle spp, Trichuris spp and Taenia spp have a relatively similar seasonal prevalence to the two (2) seasons. 


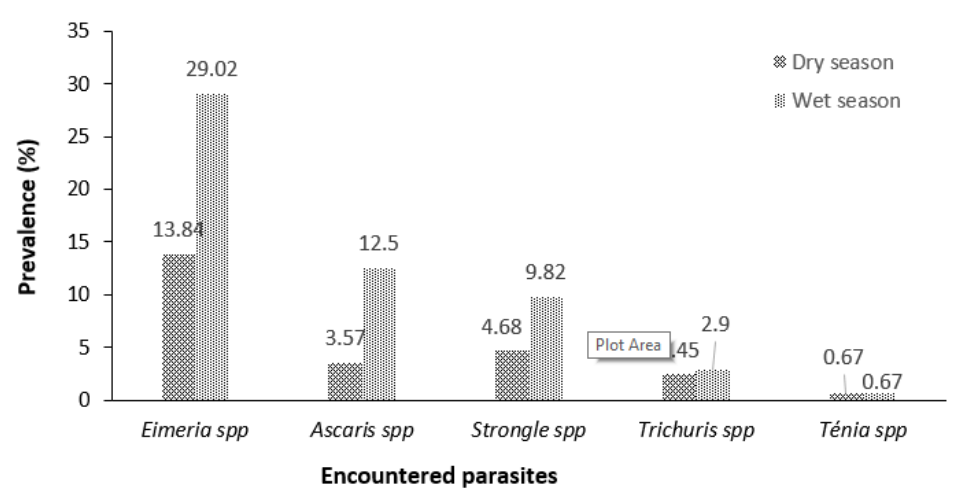

Figure 4 Seasonal parasites prevalence

\section{Discussion}

The study of the level of parasitism in fowl farms in the north of the Ivory Coast showed that the farms of the northern region of the country are generally characterized by five species of parasites including Eimeria $s p$; Ascaris sp, strangles spp; Trichuris spp and Taenia spp. The presence of these pests on these farms was due to the manner in which breeders operated. In fact, in all the fowl farms visited, the brooding of the eggs of guinea fowl is ensured by mother hens who, at hatching, drive the fowl until about two months. Furthermore, even after separation from the mother chicken, fowl flourish mixed with other poultry and share the same path until adulthood. Several studies had already shown the presence of the same species of parasites in domestic chickens in the sub-region [10;11]. Also, studies in other parts of the globe, including Ghana [12], Benin; [13], Tanzania [14] and Zimbabwe [15; 16] yielded similar results and these authors attributed the causes of this poly-parasitic behaviour to the way animals are conducted. Indeed, according to these authors, extensive driving common to almost all African countries would be the main source of infestation but also of spread of parasites.

This study also reveals a dominance of coccidiosis (42.85\%) over other parasites in the study area. This high presence of Eimeria spp could be explained by the fact that the temperature and humidity conditions are favorable for the sporulation of oocysts.

The departments of Korhogo (77.68\%) and Sinematiali (58.93\%) have the highest prevalence of Eimeria spp (Table 1). The high prevalence of Eimeria spp in these two departments could be explained firstly by the proximity between them but also by the nonuse of deparasitizing by breeders. Indeed, the proximity between these two localities facilitates exchanges between breeders. In this sense the town of Korhogo constituting the center of exchanges, receives animals, feeds, poultry vehicles and breeders from the surrounding localities. In addition, all breeders in the study area use only decoctions against the parasites.

The presence of Eimeria spp; Ascaris spp and strongle spp in guinea fowl of all age groups were close because they were the three most common parasites in other bird species with which guinea fowl live. Thus, living in the same environment, these different animals infest each other. The Taenia spp was only encountered in Sinematiali and only animals over 60 days old are affected. The presence of this parasite in adult animals is due to the fact that, in this locality, guinea fowl feed regularly goes to night parks of cattle.

With respect to seasonal distribution of parasites, the present study shows that Eimeria spp and Ascaris spp are statistically more abundant in the rainy season than the other three parasites (Strongle, Trichuris and Taenia) which have a similar prevalence at the two (2) seasons even if apparent, the wet season remains more dominant. The difference in prevalence observed during the two seasons for Eimeria spp and Ascaris spp could be attributed to the favorable conditions offered by the wet season for their development. During the wet season, temperature and relative humidity promote the proliferation of parasites while the dry season is rather unfavorable. That's the last thing. The absence of puddles of water and pools during the dry season would be one of the main causes of this low level of infestation. Moreover, during this period, breeders to water their animals, use drinking water. Similar observations were made by [17] in their study of the socio-economic attributes of fowl breeding in Ghana. According to these authors, unlike adult guinea fowl, young guinea-fowl during the first six weeks of age are need intensive care. These authors report that breeders take the fowl with them to the field and feed them with either crushed maize, sorghum or termites. 


\section{Conclusion}

The study reveals that guinea fowl are host of a variety of gastrointestinal parasites, including Ascaris spp, Strongles spp, Trichuris spp, Taenia spp and, above all, coccidia. Of the four departments that of Sinématali recorded the strongest polyparasitic. However, the highest prevalence of coccidia was recorded in Korhogo. In addition, the wet season is the period of highest parasitic prevalence, especially in animals over 21 days of age. As a result of this study, it would be interesting to propose a prophylaxis program adapted to the conditions of extensive breeding. Such program would reduce the rate of parasitic infestation of animals and thus the mortality rate.

\section{Compliance with ethical standards}

\section{Acknowledgments}

The authors thank all those which are implied in the development of this article.

\section{Disclosure of conflict of interest}

The authors have no conflict of interest to declare.

\section{References}

[1] Ayeni JSO and Ayanda JA. (1982). Studies of the Husbandry and Social Acceptance of Guinea Fowl in Nigeria. Bulletin of Animal Health and Production Africa, 30(2), 139-148.

[2] Nwagu BI and Alawa BI. (1995). Guinea fowl production in Nigeria. Journal of World's Poultry Research, 51(3), 260-270.

[3] Teye GA and Adam M. (2000). Constraints to guinea fowl production in northern Ghana: A case study of the Damongo area. Ghana Journal of Agricultural Science, 33(2), 153-157.

[4] Boko CK, Kpodekon MT, Farougou S, Dahouda M, Youssao AKI, Aplogan GL, Zanou J and Mainil JG. (2011). Farmer perceptions and pathological constraints in helmeted guinea fowl farming in the Borgou department in NorthEast Benin. African Journal of Agricultural Research, 6(10), 2348-2357.

[5] Moreki JC and Seabo D. (2012). Guinea Fowl Production in Botswana. Journal of World's Poultry Research, 2(1) 01-04.

[6] Obike OM, Oke UK and Azu KE. (2011). Comparison of egg production performance and egg quality traits of pearl and black strains of guinea fowl in a humid rain-forest zone of Nigeria. International Journal of Poultry Science, 10(7), 547-551.

[7] Tye GA and Gyawu P. (2001). The benefits of intensive guinea fowl production in Ghana. World Poultry - Elsevier, 17(9), 53-54.

[8] Boko KC, Kpodekon TM, Dahouda M, Marlier D and Mainil JG. (2012). Technical and health constraints of traditional guinea fowl production in sub-Saharan Africa. Annals of Veterinary Medicine, 156, 25-36.

[9] Dahouda M, Sènou M., Toléba SS, Boko CK, Adandédjan JC and Hornick JL. (2008). Comparison of local Guinea fowl (Numida meleagris) production characteristics in experimental station and rural area in soudano-guinean zone of Bénin. Livestock Research for Rural Development, 20(12).

[10] Maho A, Youssouf K, Mbeunodji L, Saboune M and Mopate LY. (1999). Prevalence of digestive parasites of local chickens (Gallus gallus) in North Guera, Chad. Newsletter RIDAF, 9 (1), 5-9.

[11] Hien OC, Nianogo A and Sawadogo L. (2001). Traditional breeding of the local guinea fowl in the west-central zone of Burkina. Science and technology, natural sciences and agronomy, 25 (2), 25-31.

[12] Konlan SP and Avornyo FK. (2013). The effect of wetland on guinea fowl (Numida meleagris) egg productivity and fertility during the dry season in the guinea savannah ecological zone of Ghana. Sky Journal of Agricultural Research, 2(9), 126-131.

[13] Dahouda M, Toleba SS, Youssao AKI, Kogui SB, Aboubakari SY and Hornick JL. (2007). Guinea fowl rearing constraints and flock composition under traditional management in Borgu Department, Benin. Family Poultry, $17(2), 3-14$. 
[14] Maganga SLS and Haule KS. (1998). Domestication of guinea fowl: A case of Morogoro Municipal, Tanzanie. In: Fao (eds) Wildlife and nature. International Journal Nature Conservation Africa, 14(1), 14-28.

[15] Saina, H, Kusina NT, Kusina JF, Bhebhe E and Lebel S. (2005). Guinea fowl production by indigenous farmers in Zimbabwe. Livestock Research for Rural Development, 17(9).

[16] Kusina NT, Saina H, Kusina JF and Lebel S. (2012). An insight into guinea fowl rearing practices and productivity by guinea fowl keepers in Zimbabwe. African Journal of Agricultural Research 7(25), 3621- 3625.

[17] Issaka BY and Yeboah RN. (2015). Socio-economic attributes of guinea fowl production in two districts in Northern Ghana. African Journal of Agricultural Research, 11(14), 1209-1217.

\section{How to cite this article}

Soro OS, Karamoko Y, Traoré SI and Yapi JN. (2019). Assessing Emeria spp and other parasites in the digestive track of guinea fowls (Numida meleagris) farmed in northern Côte d'Ivoire. GSC Biological and Pharmaceutical Sciences, 6(2), 90-97. 